\title{
Effects of Tension Reinforcement Ratio on Ductility of Mid-Rise Reinforced Concrete Structures
}

\author{
${ }^{1 *}$ Onur Onat and ${ }^{1}$ Burak Yön \\ *1Faculty of Engineering, Department of Civil Engineering Munzur University, Tunceli, Turkey
}

\begin{abstract}
Failure mode of reinforced concrete (RC) structures are classified according to tension reinforcement ratio of beam elements. To determine effect of tension reinforcement ratio on performance of $\mathrm{RC}$ structure, two planar RC structure were selected. One of them is 5 stories other of them is 7 stories. Two different concrete class, $\mathrm{C} 20$ and $\mathrm{C} 25$, were considered for analysis. Three tension reinforcement combinations were considered, three different tension reinforcement ratios were used. First case is the ratio of the tension reinforcement is lower than that of the compression reinforcement, second case is the ratio of the tension reinforcement is equal to the ratio of the compression reinforcement and third case is the ratio of the tensile reinforcement is higher than the compression reinforcement.
\end{abstract}

Key words: Reinforced concrete structures, tension reinforcement, fiber element, nonlinear static analysis

\section{Introduction}

Tension or compression reinforcement ratio may change due to external effects such as corrosion and deterioration of rebars as reported by Theriaule and Benmokrane (1998) [1]. It was reported that two important parameters have influenced on performance of bar ratio change. One of them is propagated crack width, other of them is crack spacing. These two factors are restricted with tension reinforcement ratio [1]. Fantilli et al. (1999) investigated tension reinforcement ratio on structural performance on the base of bond-slip behavior [2]. Minimum steel bar ratio is affected by bar diameter. Thus, bond slip behavior is profoundly affected by bar diameter [2]. Ashour (2000) experimentally investigated tension reinforcement ratio on the high-strength beam behavior. Increasing compressive strength allowed beam to behave more flexible [3]. Lee and Pan (2003) investigated concrete confinement and spalling of concrete on the base of tension rebar ratio. Lee and Pan draw attention to fulfill ductility of structural members during design phase [4]. In this paper, it is aimed to investigate the effect of tension reinforcement ratio of beam on ductility of RC structures. For this purpose, two RC structure were selected. One of them is 5 stories and other of them is 7 stories. Two different concrete compressive strength were considered.

\section{Numeric Model and Method}

Both model in this study were defined with fiber element model which accounts plasticity. This plasticity is spread through to the cross-section and the length of the element. In this hinge model,

*Corresponding author: Address: Faculty of Engineering, Department of Civil Engineering Munzur University, 62000, Tunceli TURKEY. E-mail address: onuronat@munzur.edu.tr, Phone: +904282131794/2424 
the structural element is divided in three types of fibers: some fibers are used for modelling of longitudinal steel reinforcing rods; some of fibers are used to define nonlinear behaviour of confined concrete which consists of core concrete; and other fibers are defined for unconfined concrete which includes cover concrete. Also, for each fiber, the stress/strain field is determined in the nonlinear range by using constitutive laws according to defined materials. Figure 1 shows typical fiber modelling for a rectangular reinforced concrete section.
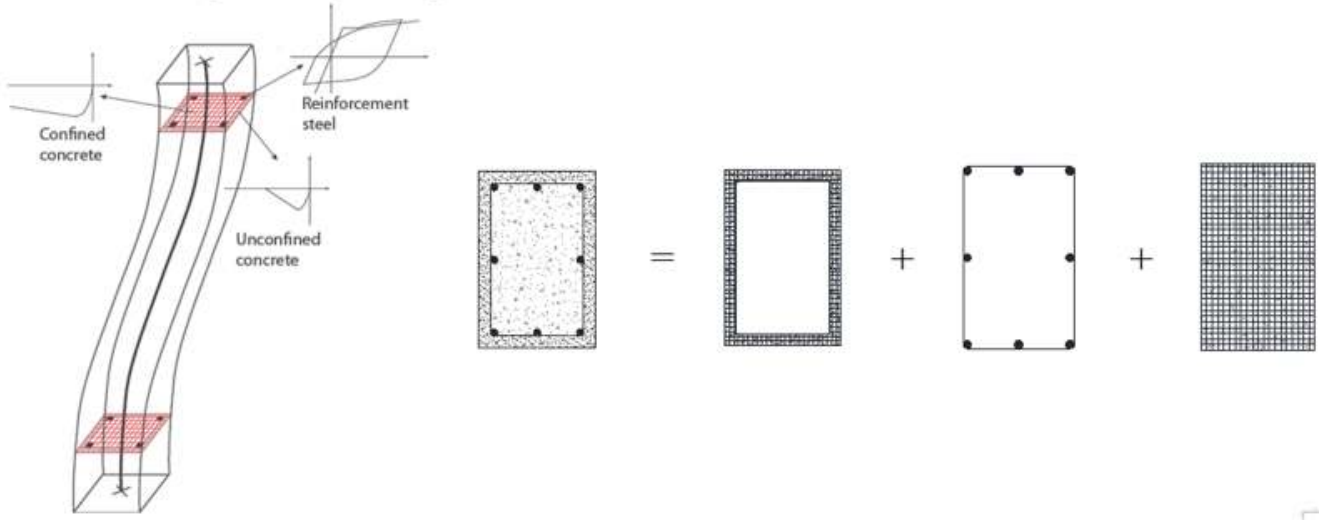

Figure 1. Typical fiber model of a RC element [5]

\subsection{Description of Numeric Model}

Numeric models were modelled with 5 storeys and 7 storeys RC frame. Both of the RC frames have 5 bays and width of the bay is $5 \mathrm{~m}$. Two different concrete compressive strength were considered C20 and C25 and yield strength of rebar $420 \mathrm{MPa}$. Columns were not jacket in this study. One of the models was presented in Figure 2. Each floor was $3.0 \mathrm{~m}$ constant story height. The dimensions for columns were selected as $40 \mathrm{~cm} / 40 \mathrm{~cm}$ for 5 story building and $50 \mathrm{~cm} / 50 \mathrm{~cm}$ for 7 story building. Moreover, dimensions of beams were selected as 30/50 for both buildings. The nonlinear static analyses of the buildings were performed indicated in Turkish Seismic Code (TSC) [6]. The building importance coefficient is assumed as 1.0 for the existing building. Boundary condition of the building was supposed as fixed support. Also, the soil differences and damping properties accordance with soil were not considered. For nonlinear analyses, SeismoStruct [7] program was used which is able to simulate the inelastic structural systems response. 


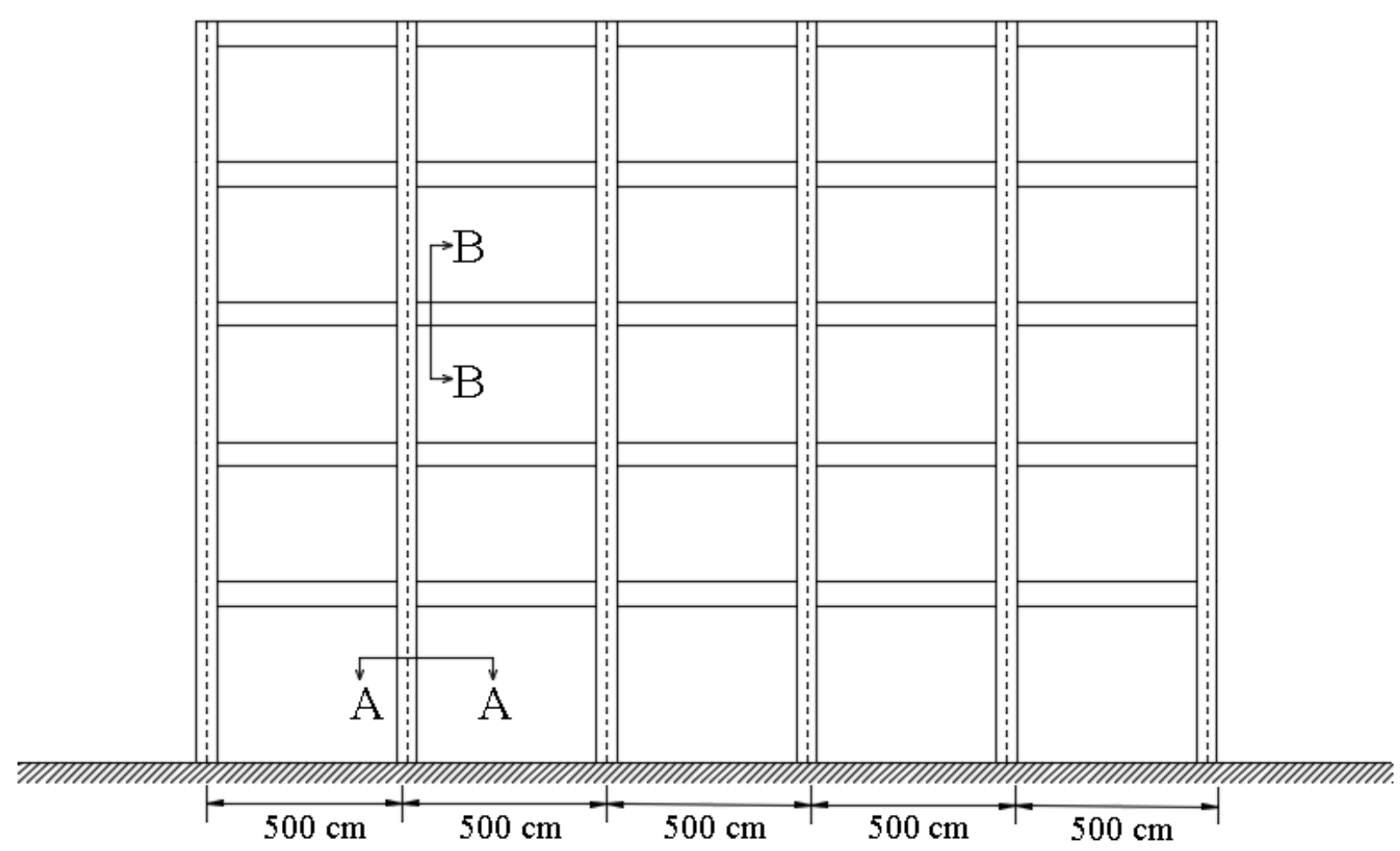

a)

Columns

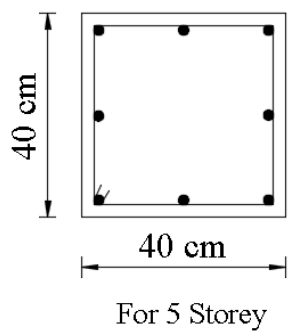

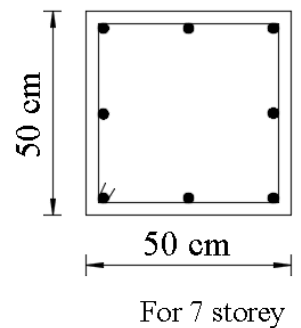

Section A-A
Beams

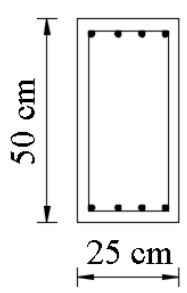

Section B-B

b)

Figure 2. a)Generic 5 storey model, b) Cross sections

\subsection{Adopted Material Models and Properties}

The bilinear elastic plastic material model which includes kinematic strain hardening is used for the reinforcing bar. Concrete material is defined by the uniaxial confinement concrete model (Figure 3) [8,9]. The confinement effect is calculated by using Mander model [10]. Reinforced concrete parameters related to structural elements are illustrated in Table 1. 


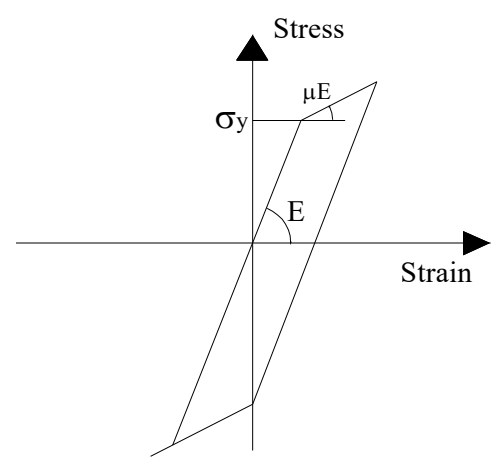

a) Reinforcing bar

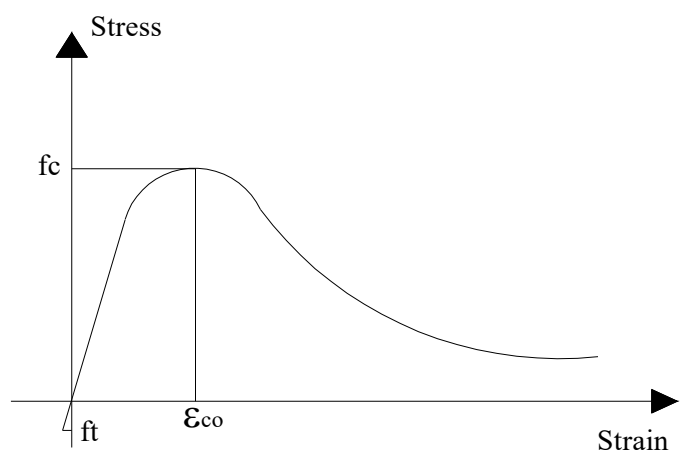

b) Concrete

Figure 3. Material models for reinforcing bar and concrete

Table 1. Reinforced concrete parameters related to structural elements.

\begin{tabular}{ccccc}
\hline \multicolumn{2}{c}{ Structural Elements } & $\begin{array}{c}\text { Longitudinal } \\
\text { reinforcement }\end{array}$ & Section & $\begin{array}{c}\text { Transverse } \\
\text { reinforcement } \\
\text { spacing (cm) }\end{array}$ \\
\hline $\begin{array}{c}\text { Column } \\
(50 / 50\end{array}$ & $\begin{array}{c}\text { Confinement } \\
\text { zone of column } \\
\text { and } \\
\text { Central zone of } \\
\text { column }\end{array}$ & $8 Ø 16$ & A-A & 15 \\
$40 / 40)$ & $\begin{array}{c}\text { Confinement } \\
\text { zone of beam } \\
\text { Beam }\end{array}$ & $\begin{array}{c}\text { Top reinforcement } \\
2 \varnothing 12\end{array}$ & A-A & 15 \\
$(25 / 50)$ & $\begin{array}{c}\text { Central zone of } \\
\text { beam }\end{array}$ & $\begin{array}{c}\text { Bottom reinforcement } \\
4 \varnothing 12\end{array}$ & B-B & 20 \\
\hline
\end{tabular}

Model-I represents $\frac{\rho}{\rho^{\prime}}=\frac{1}{2}$, Model-II represents $\frac{\rho}{\rho^{\prime}}=1$, Model-III represents $\frac{\rho}{\rho^{\prime}}=\frac{3}{2}$. Where $\rho^{\prime}$ represents rebar area of compression reinforcement, $\rho$ represents rebar area of tension reinforcement.

\section{Results and Discussion}

Results of the performed analysis were presented with two different graphs. One of the graphs was performance graphs contains base shear and roof displacement, other of them is interstorey drift versus floor number. Capacity curves of the 7 storey and 5 storey models were presented in Figure 4 a) and Figure $4 b$ ) respectively. 


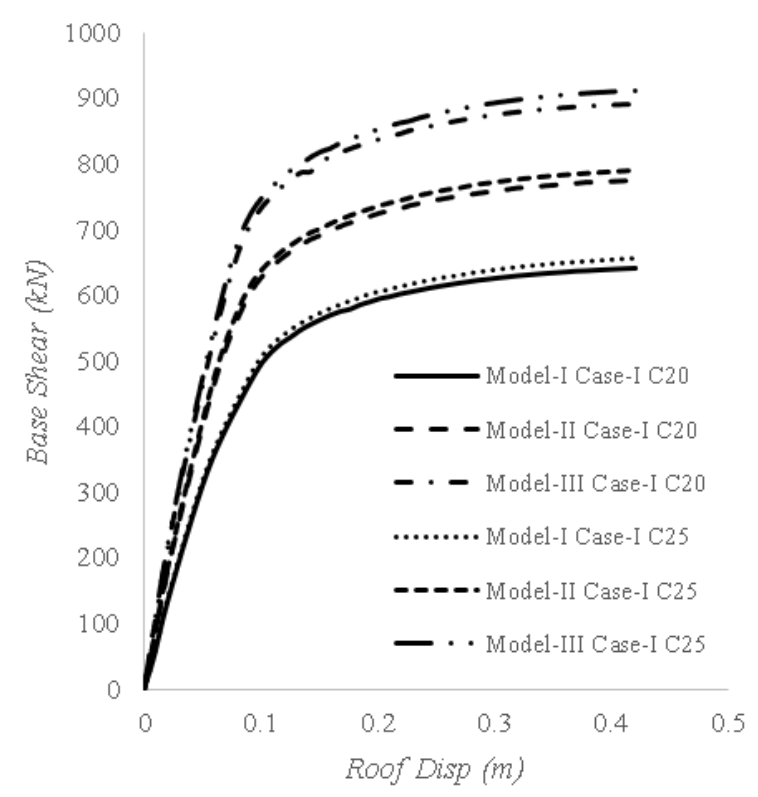

a)7 Storey model

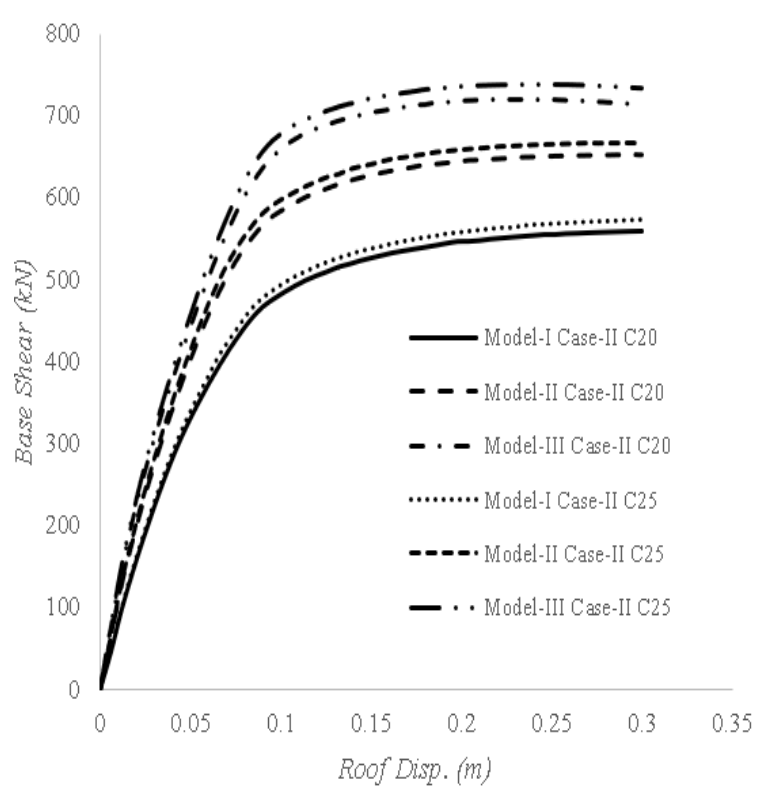

b)5 Storey model

Figure 4. Capacity curves of the two models

Figure 4 presents capacities of the two models according to performed analysis. After performed analysis, obtained maximum values were tabulated in Table 2.

Table 2. Maximum base shear and maximum roof displacements.

\begin{tabular}{|c|c|c|c|c|c|c|c|c|c|c|c|c|}
\hline & \multicolumn{9}{|c|}{ 5 Storey } & \multicolumn{9}{c|}{ M Storey } \\
\cline { 2 - 12 } & \multicolumn{2}{|c|}{ Model-I } & \multicolumn{2}{|c|}{ Model-II } & \multicolumn{2}{c|}{ Model-III } & \multicolumn{2}{c|}{ Model-I } & \multicolumn{2}{c|}{ Model-II } & \multicolumn{2}{c|}{ Model-III } \\
\cline { 2 - 12 } & $\mathrm{C} 20$ & $\mathrm{C} 25$ & $\mathrm{C} 20$ & $\mathrm{C} 25$ & $\mathrm{C} 20$ & $\mathrm{C} 25$ & $\mathrm{C} 20$ & $\mathrm{C} 25$ & $\mathrm{C} 20$ & $\mathrm{C} 25$ & $\mathrm{C} 20$ & $\mathrm{C} 25$ \\
\hline $\begin{array}{c}\text { Max. } \\
\text { Base Shear } \\
(\mathrm{kN})\end{array}$ & 560 & 573 & 653 & 667 & 720 & 737 & 641 & 656 & 775 & 791 & 891 & 912 \\
\hline
\end{tabular}

As seen from Table 2, increasing concrete compressive strength $5 \mathrm{MPa}$ contributes overall structural performance around $2.38 \%$ for both models. However, increasing compression rebar area with constant tension rebar increases overall structural lateral resistance $16 \%$ while compared Model-II with Model-I. Moreover, this increase ratio decreased to 10\% while compared Model-III and Model-II. This contribution ratios are common for two different storey structural system, i.e. 5 storey and 7 storey. After performing analysis, interstorey drifts were evaluated on the base of TSC 2007 [11] by using Equation 1 and Equation 2.

$\delta_{i}=R * \Delta_{i}$

Where $\Delta_{i}$ is the obtained lateral displacement, $R$ is the global behaviour factor of structural system, $\delta_{i}$ is the effective lateral displacement.

$\frac{\left(\delta_{i}\right)_{\max }}{h_{i}} \leq 0.02$

$h_{i}$ is the story height of the investigated structure. Result of Equation 2 is should be lower than 
0.02

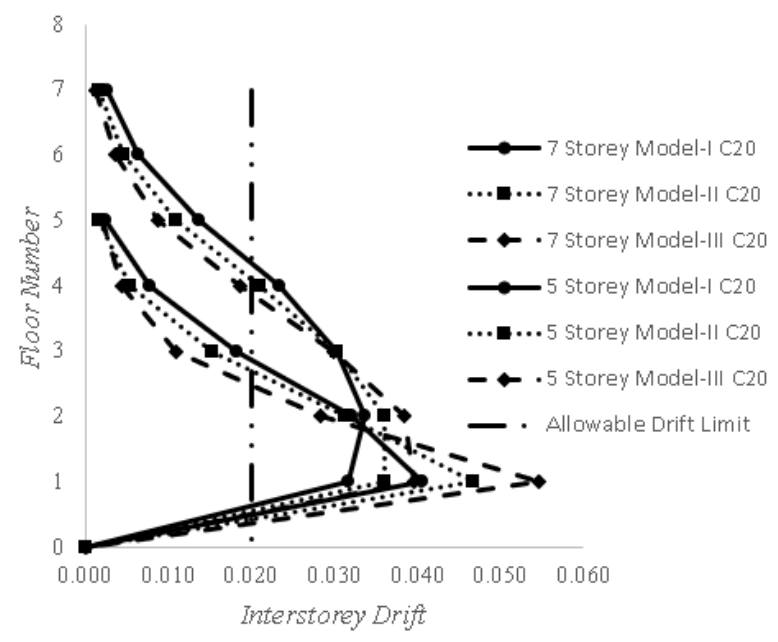

a)Drift results for two model with $\mathrm{C} 20$

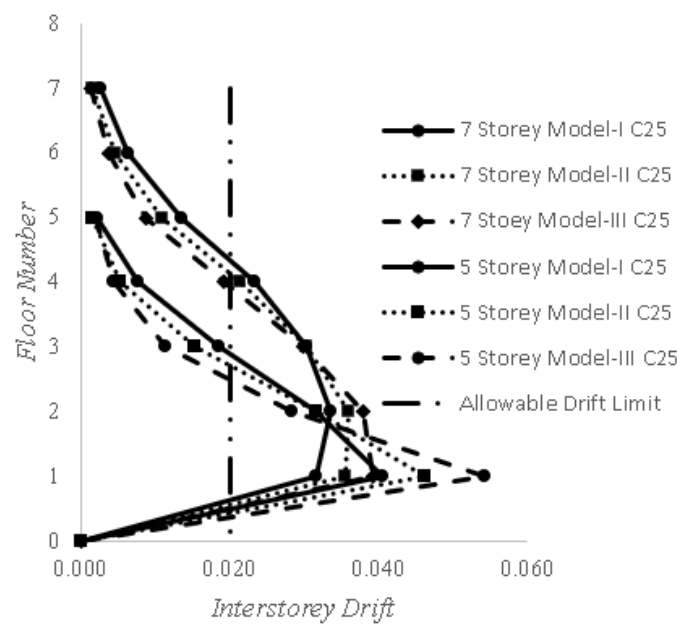

b)Drift results for two model with $\mathrm{C} 25$

Figure 5. Drift results for all models with two different compressive strength test results

Interstorey drift is one of the most important criteria to see structural response under any type of loading. For this purpose, Figure 5 was plotted to observe structural behavior under varying conditions. Table 3 was tabulated to see maximum interstorey drift in percent.

Table 3. Maximum interstorey drifts and code limitation.

\begin{tabular}{|c|c|c|c|c|c|c|c|c|c|c|c|c|}
\hline & \multicolumn{9}{|c|}{ 5 Storey } & \multicolumn{9}{c|}{ 7 Storey } \\
\cline { 2 - 12 } & \multicolumn{2}{|c|}{ Model-I } & \multicolumn{2}{c|}{ Model-II } & \multicolumn{2}{c|}{ Model-III } & \multicolumn{2}{c|}{ Model-I } & \multicolumn{2}{c|}{ Model-II } & \multicolumn{2}{c|}{ Model-III } \\
\cline { 2 - 12 } & $\mathrm{C} 20$ & $\mathrm{C} 25$ & $\mathrm{C} 20$ & $\mathrm{C} 25$ & $\mathrm{C} 20$ & $\mathrm{C} 25$ & $\mathrm{C} 20$ & $\mathrm{C} 25$ & $\mathrm{C} 20$ & $\mathrm{C} 25$ & $\mathrm{C} 20$ & $\mathrm{C} 25$ \\
\hline $\begin{array}{c}\text { Max. } \\
\begin{array}{c}\text { Interstorey drift } \\
\text { (\%) }\end{array}\end{array}$ & 3.4 & 3.4 & 3.6 & 3.6 & 4.0 & 3.9 & 4.1 & 4.1 & 4.7 & 4.6 & 5.5 & 5.4 \\
\hline
\end{tabular}

As seen from the Figure 5 and Table 3, Storey number 1 and 2 have not provided allowable limits of TSC 2007 at 5 storey building model. In addition, storey number 1, 2, 3 and 4 have not satisfied $2.0 \%$ allowable limit as presented TSC 2007. Since, concrete compressive strength was increased from $20 \mathrm{MPa}$ to $25 \mathrm{MPa} 3^{\text {rd }}$ storey of 5 storey building was satisfied. However, $5 \mathrm{MPa}$ compressive strength increase has not enough for 7 storey building.

\section{Conclusions}

In this paper, it is aimed to investigate the effect of tension reinforcement ratio of beam on ductility of RC structures. For this purpose, two RC structure were selected. One of them is 5 stories and other of them is 7 stories. Two different concrete compressive strength were considered, i.e. 20 $\mathrm{MPa}$ and $25 \mathrm{MPa}$. Nonlinear static analysis was performed on the models to see structural response. According to results, increasing tension reinforcement of beam elements has not any effect on maximum roof displacement. Whereas, tension reinforcement increases decreased interstorey drift ratio. However, this ratio has not reached expected level. $5 \mathrm{MPa}$ compressive strength increase retained only one storey of structural system at 5 storey building model. This increase has not 
prevented drift level as expected level at 7 storey building.

\section{Examples:}

[1] Theriault, M., and Benmokrane, B., Effects of FRP reinforcement ratio and concrete strength on flexural behavior of concrete beams. Journal of composites for construction, 1998, 2.1: 716.

[2] Fantilli, A. P., Ferretti, D., Iori, I., and Vallini, P., Behaviour of R/C elements in bending and tension: the problem of minimum reinforcement ratio. In: European Structural Integrity Society. Elsevier, 1999. p. 99-125.

[3] Ashour, S. A. Effect of compressive strength and tensile reinforcement ratio on flexural behavior of high-strength concrete beams. Engineering structures, 2000, 22.5: 413-423.

[4] Lee, T., Pan, A. D.. Estimating the relationship between tension reinforcement and ductility of reinforced concrete beam sections. Engineering Structures, 2003, 25.8: 1057-1067.

[5] Rodrigues, H. (2012). Biaxial seismic behaviour of reinforced concrete columns. PhD Thesis, Universidade de Aveiro.

[6] Turkey Ministry of Environment and Urbanization, Turkish Earthquake Code 2007, Ankara, Turkey.

[7] SeismoStruct v7- A computer program developed for the accurate analytical assessment of structures, subjected to earthquake strong motion. Available online: www.seismosoft.com [September 8, 2014].

[8] Kwon, O.S. and Kim, E. Case study: Analytical investigation on the failure of a two-story RC building damaged during the 2007 Pisco-Chincha earthquake. Engineering Structures, 2010, $32,1876-1887$.

[9] Duan, H. and Hueste, M.B.D. Seismic performance of a reinforced concrete frame building in China. Engineering Structures, 2012, 41, 77-89.

[10] Mander, J.B., Priestley, M.J.N., Park, R., Theoretical stress-strain model for confined concrete, Journal of Structural Engineering (ASCE), 1988, pp. 1804-1826.

[11] TEC 2007, Turkish Earthquake Resistant Design Code, Ministry of Public Works and Settlement, Ankara, 2007 